ISSN: 2349-2031

Research Article

\title{
A Study of Consumer Attitudes towards Mobile Advertising among the Undergraduates of University of Jaffna Srilanka
}

\author{
${ }^{1}$ Sivanenthira S, ${ }^{2}$ Ratnam E, ${ }^{3}$ Sabina D \\ ${ }^{1}$ MBA Programme University of Jaffna \\ ${ }^{2}$ Department of Marketing University of Jaffna \\ ${ }^{3}$ Department of Commerce University of Jaffna
}

\begin{abstract}
The mobile advertisement has played a major role in the day today life. Currently around 4.9 billion people in the world own 7.19 billion mobile subscriptions, consequently as a developing country Sri Lanka the number of mobile phone use is $\mathbf{2 2 . 1}$ million. Especially youth has used the mobile devices rapidly and active with mobile advertisements. More over University undergraduates very much spend time with the mobile phones and searching the advertisements and entertainment activities via mobile phone and WAP (wireless application protocol) facilities helps to involve the UOJSL (University of Jaffna, Sri Lanka) undergraduates to more user friendly with mobile phones. In this research the deductive approach has been implemented in order to answer the research questions. Quantitative data has been collected through a questionnaire. The statements used in the questionnaire are based on previous studies and theories. The data retrieved through the questionnaire has been analyzed using SPSS 21. The results of this study showed the UOJSL undergraduates mainly consumer based acceptance drivers and innovation based acceptance driver's levels are highly determining on attitudes towards mobile advertising. Furthermore, it was found that the more positive the attitude toward advertising in general is, and the more the consumer likes searching for product information. The main purpose of this research was to find out what the attitudes of the UOJSL undergraduates are toward mobile advertising. The statistical results showed a positive attitude toward mobile advertising.
\end{abstract}

Key words: Mobile Advertising, Consumer Based Acceptance Drivers and Innovation Based Acceptance Drivers

\subsection{Background of the Study}

In the business environment customers are the king of the business. To attract customer's business organizations, engage with promotional activities. They are many types of promotional mix such as product, price, place and promotion. Advertising is a subset of promotional mix, Advertisements tend to be highly informative \& present the customer with a number of important product attributes or features that will lead to favorable attitudes and can be used as the basis for a rational brand preference. In the past advertisement done via mass media such as televisions, newspapers and radio, but the development of the technology internet place a major contribution towards advertising after the evolution of mobile usages and arrival of the android and iPhone phones helps to fundamental changes with advertising .Its means marketing activities that are performed via mobile device allow precise targeted advertising and interactivity, but has yet to fulfill the expectations and materialized as researchers and analysts have forecasted (Idean,2009). Furthermore, "a killer application" is yet to be developed that would push the adoption of mobile marketing over the tipping point in gaining a critical mass to reach the early majority market and financial success. Mobile phones are considered very personal devices and an integrated part of people's daily lives. They are often considered fashion statements and users seem to assign different symbolic meaning to their mobile phones (Katz \& Sugiyama, 2006).
Moreover, Katz and Sugiyama (2006) suggest that people incorporate mobile phones into their self-image and rely on them as status markers. Furthermore, mobile phones are no more used only for making voice calls and sending messages, but due to technical advancements, mobile phones have become pocket-sized computers and entertainment devices, referred as smart phones, that offer a plethora of uses and functions in areas such as entertainment, photography and Internet connectivity often utilizing touch sensitive user interfaces to access these applications. The essence of smart phones has been characterized as "anytime, anywhere and anything" (Wagner,2011). This digitalization has resulted in which offers richer possibilities to reach consumers and interact with them. However, in order to fully exploit the potential of the mobile phone as an advertising channel, marketers must understand the unique characteristics related to it and the ways that consumers interact with this channel.

\subsection{Research Problem}

The ubiquity of messaging and WAP based mobile communication creates new opportunities for marketers. The increasing adoption of mobile telephony and ongoing diffusion of mobile phones have encouraged marketers to advertise through the Mobile. However, there are only few studies being conducted about Sri Lankan mobile users' attitudes towards advertising. In addition, the factors that 
induce consumers to accept mobile devices as an advertising medium are not yet fully understood. This study attempts to fill this gap by studying the university of Jaffna Sri Lanka undergraduates' attitudes towards mobile advertising. This country has been chosen because of its high use and adaptation concerning the technical developments of the internet. With use of the research findings recommendations can be made toward companies on how and when to use mobile advertising and how to improve their current use of mobile advertising. And, most empirical evidence come from the developed economies such as the united states of America (USA), the United Kingdom (UK), Canada and Australia There seems to be a lack of evidence from developing countries, but and limited evidence are available especially in Sri Lanka. Ranathunga R.M.K.B (2010),L.N.Liyanage(2015). According to the above issue the problem statement as follows: "What is the attitude of undergraduates from UOJ towards mobile advertising?"

\subsection{Research Objectives}

- To identify the relationship between consumers based acceptance drivers towards mobile advertising.

- To identify the relationship between Innovations based acceptance drivers towards mobile advertising.

\subsection{Literature Review}

According to Haghirian\&Madlberger (2005) the most important dimensions considering consumers' attitudes toward mobile advertising are entertainment and in formativeness. These results comply with the results of the study of Bauer et al (2005). The results of Haghirian\&Madlberger(2005) also showed credibility to be an important factor concerning the attitudes of consumers. In this research credibility is based on the extent to which consumers believe that the marketer has the expertise and honesty to perform a transaction effectively and reliably. The dimension credibility of Haghirian\&Madlberger (2005) complies with the dimension concerning perceived risk of Bauer et al (2005). Haghirian\&Madlberger (2005) also take consumer demographics into account when studying consumer attitudes toward mobile advertising, which Bauer et al (2005) do not. However, their findings show that demographics do not have any influence on the attitudes of consumers, except for the attitude toward privacy. Consumers who consider privacy very valuable are less likely to attribute a high value and a positive attitude toward advertising via mobile devices. Ackerman et al (2001) assume that consumers accept a certain degree of privacy loss if the benefit is considered being sufficient and satisfying. However, privacy concerns cannot be dismissed. A high frequency of exposure does not reflect either positively or negatively on consumers' attitude toward advertising via mobile devices.

Another research studying the drivers of mobile advertising acceptance is the research conducted by Merisavo et al (2007). This research focused on Finnish consumers and evaluated five possible drivers namely utility, context, control, sacrifice and trust. Further research on mobile advertising was conducted by Mir (2011), who says mobile advertising is emerging as a new channel of marketing communication. Mir (2011) found that consumer attitudes toward mobile advertising tends to turn positive when the messages are send after the consumer giving permission for sending the advertising messages. Furthermore, mobile users like receiving advertising messages that are customized to their profile. This research also showed that mobile users' attitudes tend to be more positive when the advertising message is creative and the content is informative and entertaining. Wais\& Clemons (2008) conducted research on how to apply mobile advertising, focusing on American students. From their research they found the American youth prefers to receive promotional messaging not from a company but instead from another person, like a friend or relative, this would make the advertisement be perceived more positively. The research showed the risk of brand damage due to mobile advertising is lessened when the advertisement is not send directly from the company. The mobile telephone users in Sri Lanka have increased rapidly over the year 2011 with more than 105 telephone connections for 100 people, according to a Central Bank annual report, telephone connections have increased 5.4 percent and the connections increased to 21.9 million by the end of 2011, a spokesperson from the Central Bank said. 'There is also a considerable increase in the Internet connections as new connections have increased by 4 percent over the year 2011, he stated. The country`s population is estimated at 21.4 million. He said the increase in the mobile phone use in the country is partly due to the end of three decades of civil war in the northern and eastern parts of the country, reported 'Xinhua' Many of the new connections are obtained by those who were in the former war affected parts of the country and the competition in the mobile telephone connection providers has also increased the number of new connections in the country. A recent study also revealed that the use of mobile phones has grown rapidly among the poor in Sri Lanka and the mobile phone has become an almost indispensable business tool among small entrepreneurs and farmers.

\subsection{Conceptual Framework}

This conceptual framework is use to illustrate the relationship between the variables, which are involved in the study. Based on the literature review conceptual framework was developed. In this study, the consumers' attitudes towards mobile advertising are examined with the help of independent variables of Consumer based acceptance drivers and Innovation based acceptance drivers.

\subsection{Methods of Data Collection}

This research is mainly based on the primary data. Selfreported questionnaires were used in order to collect data from the 200 undergraduates. Here customers mean undergraduates and Structure questionnaire was used to collect data necessary to meet the purpose and objectives of the study.

\subsection{Methods of Data Analysis.}


Any research finally leads to a result, which would be analyzed from the data that have been received by the researcher. Data Analysis is meant to be at the most sensitive part of any research work, on achieving this various mode can be adopted. Here the collected data from the questionnaires were analyzed and evaluated by using inferential analysis.

\section{Reliability}

Reliability defined as "the degree to which measures are free from error and therefore yield consistent results" (Zikmund,2000). Reliability estimates are used to evaluate the stability of measures administered at different times to the same individuals or the equivalence of sets of items from the same test (Carole \& Almut, 2008). According to Carole \& Almut(2008) Cronbach's alpha Coefficient (CAC) is the most accepted index in testing and evaluating the reliability of data for internal consistency. Cronbach's alpha Coefficient (CAC) ranges vary from 0 to 1 and values close to 1.00 indicating high consistency, and value close to 0 indicating no consistency. Godard, Ehlinger \& Grenier (2001) and Malhothra et al(2005) indicate that the data can be reliable, when the CAC is more than or equal to 0.7 . This condition is satisfied in this study. Therefore, all the dimensions are considered to be reliable.

\begin{tabular}{|l|c|c|}
\hline Variables & $\begin{array}{l}\text { Number of } \\
\text { statements }\end{array}$ & $\begin{array}{l}\text { Cronbach's Alpha } \\
\text { coefficient }\end{array}$ \\
\hline $\begin{array}{l}\text { Consumer Based } \\
\text { acceptance drivers }\end{array}$ & 8 & 0.701 \\
\hline $\begin{array}{l}\text { Innovation Based } \\
\text { acceptance drivers }\end{array}$ & 8 & 0.830 \\
\hline $\begin{array}{l}\text { Attitudes toward } \\
\text { mobile advertising }\end{array}$ & 4 & 0.800 \\
\hline
\end{tabular}

(Source: Survey data)

\section{Correlation Analysis}

Correlation measures how variables are related. Pearson's correlation coefficient is a measure of linear association. In this study, the Pearson's correlation coefficient with two-tailed test of significance was considered since the data was quantitative and normally distributed variables. This analysis was made to investigate the relationship between the variables.

\begin{tabular}{|c|c|c|c|}
\hline \multicolumn{4}{|c|}{ Correlation Analysis: Pearson Correlation } \\
\hline & & $\begin{array}{c}\text { Consumer Base } \\
\text { Acceptance Drivers } \\
\text { CBAD }\end{array}$ & $\begin{array}{c}\text { Innovation Based } \\
\text { Acceptance } \\
\text { Drivers } \\
\text { IBAD }\end{array}$ \\
\hline \multirow{3}{*}{$\begin{array}{c}\text { Attitudes } \\
\text { of Mobile } \\
\text { Advertising } \\
\text { AACT }\end{array}$} & $\begin{array}{c}\text { Pearson } \\
\text { Correlation }\end{array}$ & $.610^{* *}$ & $.668^{* * *}$ \\
\hline & $\begin{array}{l}\text { Sig. (2- } \\
\text { tailed) }\end{array}$ & .000 & .000 \\
\hline & $\mathrm{N}$ & 200 & 200 \\
\hline
\end{tabular}

**. Correlation is significant at the 0.01 level (2-tailed). (Source: Survey Data
Results show that there is strong positive relationship between both consumers based acceptance drivers $(\mathrm{r}=0.610)$ and innovation based acceptance drivers $(r=0.668)$ towards the attitudes of mobile advertising. So rejecting the both null hypothesis that there is a relationship between consumer based acceptance drivers, innovation based acceptance drivers towards mobile advertising.

\subsection{Discussion}

The Pearson correlation analysis is explored the relationship between $\mathrm{CBAD}$ and Aact. Based on the results the correlation between CBAD and AACT is $0.610(r=0.610, p<0.01)$. The significance is at 0.00level (2-tailed), and coefficient of correlation ( $r$ ) is greater than 0.5. Therefore, CBAD and AACT have significant and strong positive relationship. And also the first hypothesis of 'there is significant positive relationship between CBAD and AACT t' has been accepted. Thus, it is reflect that the role of CBAD significantly and positively influencing Aact Similar to this finding, the previous study conducted by Kristen Evelien, Kamphuis, Manishka and ChayaRamnarain (2012) found a significant positive correlation. Accordingly, this research also found that CBAD has significant and positive relationship with AACT. The Pearson correlation analysis is explored the relationship between IBAD and AACT indicated in Table 5.19. Based on the results the correlation between CBAD and AACT is 0.668 $(\mathrm{r}=0.668, \mathrm{p}<0.01)$. The significance is at 0.00level (2-tailed), and coefficient of correlation $(r)$ is greater than 0.5 . Therefore, IBAD and AACT have significant and strong positive relationship. And also there is significant positive relationship between IBAD and AACT' has been accepted. Thus, it is reflect that the role of IBAD significantly and positively influencing AACT Similar to this finding, the previous study conducted by Kristen Evelien, Kamphuis, Manishkaand Chaya Ramnarain (2012) found a significant posit correlation. Accordingly this research also found that IBAD has significant and positive relationship with AACT.

\subsection{Conclusions of the Research Objectives}

The study has undertaken the IBAD and CBAD as independent variables and the AACT as dependent variable and analyzed and assessed the objectives and the study has given special attention to the sample size of 200 undergraduates who are studying in the UOJSL. To accomplish the objectives of this study, the data collected from the respondents through the questionnaire. Its use for the analysis purpose and were analyzed and evaluated by using inferential analysis and research hypotheses. The results of this study showed the undergraduates, UOJSL, CBAD and IBAD levels of mobile advertising as positive in comparison to traditional forms of advertising. Furthermore, Perceived utility was shown to be an important factor in order for the consumer to perceive the advertising as positive. The message has to be of value to the consumer, meaning it has to contain timely information and preferably provide the consumer with an incentive such as a coupon or free item. Furthermore, the results showed that for an advertisement Furthermore, the 
results showed that for an advertisement to be accepted by UOJSL undergraduates, the advertiser must have gained permission of the consumer before sending it.

\subsection{Recommendation}

This research is focused on the attitudes of the UOJSL undergraduates only toward mobile advertising. However, with the technology trend every one using the mobile phones, we think it would be interesting to find out what is Sri Lankan users between attitudes toward mobile advertising of the of mobile phones. Furthermore, this research is completely focused on a University undergraduate. Therefore, we think it would be interesting to find out how the businessmen perceives on attitudes toward mobile advertising.

\section{References}

[1] Parasuraman, V.A. Zeithaml, and A. Malhotra (2005), "ES-QUAL: A multiple-item scale for assessing electronic service quality"

[2] Aaker, D. A., Kumar, U. and Day, G.S. (1995). Marketing research (5thed.). New York: John Wiley

[3] Ananda P.H.D.I. ${ }^{1}$, Seneviratne W.D.J.G.C. ${ }^{1}$, Guruge B.A. ${ }^{1}$, Abeywickrama D.M.N. ${ }^{1}$, (2010) Mobile and internet usage among Sri Lankan undergraduates.

[4] Arens, Williams F. 1996. Contemporary Advertising.USA: Richard D. Irwin, A. Times Mirror Higher Education Group Inc. Company

[5] Bauer, H., Barnes, S., Reichardt, T., \&Neurnann, M. (2005). Driving Consumer Acceptance of Mobile Marketing: A Theoretical Framework and Empirical Study. Journal of Electronic

[6] Beneke, J., Cumming, G., Stevens, A., \&Versfeld, M. (2010), 'Influences on Attitude toward Mobile Text Message Advertisement: An Investigation of South African Youth', International Journal of Mobile Marketing, Jun2010, Vol. 5 Issue 1, p77-97, 21p.

[7] Chowdhury, H. K. Parvin, N. Weitenberner, C. \& Becker, M. (2006). Consumer Attitude toward Mobile Advertising in an Emerging Market: An Empirical Study, International Journal of Mobile Marketing, Vol.1 (2), 3342.

[8] Chowdhury, H., Parvin, N., Weitenberner, C., \& Becker, M. (2006), 'Consumer Attitude toward Mobile Advertising in an Emerging Market: An Empirical Study', International Journal of Mobile Marketing, Vol. 1, Issue. 2, p33-41, 9p.

[9] Drossos, D., Giaglis, G., Lekakos, G., Kokkinaki, F., \&Stavraki, M. (2007), 'Determinants of Effective SMS Advertising: An experimental Study', Journal of Interactive Advertising, Spring2007, Vol. 7 Issue 2, p122, 23p.

[10] Godard, Ehlinger\&Grenier (2001) Doing Management Research A comprehensive Guide

[11]Haghirian, P., \&Madlberger, M. (2005), 'Consumer Attitude toward Advertising via Mobile

[12] Hanley, M., and Becker, M. (2008). Cell Phone Usage and Advertising Acceptance among College Students: A
Four-Year Analysis. International Journal of Mobile Marketing, 3(1), 67-80.

[13] Hanley, M., Becker, M., \&Martinsen, J. (2006), 'Factors Influencing Mobile Advertising Acceptance: Will Incentive Motivate College Students to Accept Mobile Advertisements?', International Journal of Mobile Marketing, Vol. 1, Issue 1, p50-58, 9p.

[14] Heath, R. G. and Stipp, H. 2011. The secret of television's success: emotional content or rational information? After fifty years the debate continues. Journal of Advertising Research, 51 (1), pp. 112-123.

[15] Katz, E., Haas, H., \&Gurevitch, M. (1973), 'On the Use of the Mass Media for Important Things', American Sociological Review, Vol. 38, Issue 2, p164-181, 18p.

[16] Katz, J. E., \& Sugiyama, S. (2006). Mobile phones as fashion statements: Evidence from student surveys in the US and Japan. New Media and Society, 8 (2), 367-383.

[17] Kavassalis, P., Spyropoulou, N., Drossos, D., Mitrokostas, E., Gikas, G., \&Hatzistamatiou, A. (2003), 'Mobile Permission Marketing: Framing the Market Inquiry', International Journal of Electronic Commerce, Vol. 8, Issue 1, p55-79, 15p.

[18] Kondo, F., Jian, S., \&Shahriar, A. (2008), 'Gradual Changes in Repeat Customers: Adoption Behaviour towards Responses', International Journal of Mobile Marketing, Dec2008, Vol. 3, Issue 2, p15-24, 10p.

[19] Kotler, P., Wong, V., Saunders, J., \& Armstrong, G. (2005), 'Principles of marketing', 4thEuropean edition, Harlow, Financial Times Prentice Hall

[20] Kristen Evelien Kamphuis,Manishka Chaya Ramnarain(2012),Consumer Attitudes toward Mobile Advertising A Study of Dutch Youth.

[21] Kroeber-Riel, W., \& Weinberg, P. (2003), 'Konsumentenverhalten', 8th Ed., Vahlen, München.

[22] L.N.Liyanage(2015)usage of mobile phone among university students in Sri Lanka.

[23]Leavitt, C., \& Walton, J. (1975), Development of a Scale for Innovativeness', Advances in Consumer Research, Vol. 2, Issue 1, p545-555, 11p.

[24]Leppäniemi, M., \&Karjaluoto, H. (2005), 'Factors Influencing Consumers' Willingness to Accept Mobile Advertising: A Conceptual Model', International Journal of Mobile Communications, 2005, Vol. 3, Issue 3, p1-1, $1 \mathrm{p}$.

[25]Lohse, G., \& Rosen, D. (2001), 'Signaling Quality and Credibility on Yellow Pages Advertising: The Influence of Color and Graphics on Choice', Journal of Advertising, Vol. 30, p73-85, 13p.

[26] Paavilainen, J. (2002), 'Mobile Business Strategies: Understanding the Technologies and Opportunities'. London: Addison Wesley.

[27]Peng, B. (2006), 'Mobile Marketing - The Chinese Perspective', International Journal of Mobile Marketing, Vol. 1, Issue 2, p50-59, 10p.

[28] Schlosser, A. (2003), 'Experiencing Products in the Virtual World: The Role of Goal and Imagery in Influencing Attitudes Versus Purchase Intentions', 
Journal of Consumer Research, Vol. 30, p184198, 15p.

[29] Van der Waldt, D., Rebello, T., \& Brown, W. (2009), 'Attitudes of Young Consumers towards SMS Advertising', African Journal of Business Management, Sep2009, Vol.3, Issue 9, p444-452, 8p.

[30] Vatanparast, R., \&Asil, M. (2007), 'Factors Affecting the Use of Mobile Advertising', Journal of Mobile Marketing, Dec2007, Vol. 2, Issue 2, p21-34, 14p.

[31] Wagner, J. (2011). Anytime/anywhere: playing catch up with mind of the smart phone consumer International journal of Mobile Communication, 6(1), 28-53.

[32] Wais, J., and Clemons, E. (2008), 'Understanding and Implementing Mobile Social advertising', International Journal of Mobile Marketing, Vol. 3, Issue 1, p12-18, 7p. 